\title{
Improving Student Learning Outcomes Marketing Strategy Lesson By Applying SFAE Learning Model
}

\author{
Winda Nur Rohmawati \\ Suwarni \\ Education of Commerce, Faculty of Economics, State University of Malang \\ E-mail: suwarni@fe.um.ac.id \\ Mufidah
}

SMK YPI Darussalam 2 Cerme Kabupaten Gresik

\begin{abstract}
Research objectives for improving student learning outcomes on the subjects of marketing strategy through the implementation of model learning SFAE. This type of research this is a class action research using a qualitative approach which consists of two cycles with the subject Marketing $X$ grade SMK YPI Darussalam 2 Cerme Gresik Regency. This research consists of four stages: (1) the Planning Act, (2) the implementation of the action, (3) observations (observation), and (4) Reflection. The result of the research shows that cognitive and affective learning outcomes of students have increased significantly.
\end{abstract}

Keywords: cooperative learning model of student facilitator and explaining, learning outcome, marketing strategy

Education is an effort undertaken by a person to develop the personality and abilities that exist within a person (Bohnen et al., 2016; Lows et al., 2017). This is in accordance with the vision of national education in Law no. 20 of 2003 Article 3 states that national education is functioning to develop the ability and educate the nation's children in order to develop students' potential to become democratic and responsible citizens.

Various efforts have been made by the government to realize the improvement of the quality of education in Indonesia, among others by updating the curriculum, providing training to improve the quality of teachers, procurement of teaching materials, improving facilities and infrastructure and improve the process of learning activities. There are three main things that need to be highlighted in the context of educational reform, namely curriculum reform, improving the quality of learning, and the effectiveness of learning models.

The learning model is a series of activities or an approach that can be used to improve student learning outcomes (Kucukyilmaz, Cambazogu, Aykanat, Yates, 2017; Su, Zhang, Yin, Xiao, 2017). Joyce \& Weil (in Rusman 2012: 133) says that "learning model can be used as a pattern of choice, meaning that teachers can choose appropriate learning model and efficient to create educational goals". The selection of appropriate and varied learning models can improve students' learning motivation (Hawlitschek \& Joeckel, 2017, Yilmaz, 2017) so that students actively express their opinions (Saricoban., 2014) and be able to understand the learning materials well. The use of appropriate learning model is also expected to improve student learning outcomes so that the achievement of learning objectives.

The result of an interview with Mrs Siti Rokhmah S. Pd as the Head of SMK YPI Darussalam 2 Cerme, Gresik Regency and Mrs Mufidah S. Pd as marketing teacher said that during this time the teacher while teaching in class still using conventional methods such as lecture method, discussion, direction, and practice questions. When the learning process takes place, the students look bored because the material explanation is too long and much confuses the students to understand the material presented by the teacher, the teacher's explanation is monotonous, besides the teacher also play a more active role than the students (Tyabaev, 
2015). In addition, students also still look awkward to argue or express ideas in the classroom. This causes the learners to be less effective (Amran et al., 2016) so that student learning outcomes are less than optimal.

Learning outcomes are changes in attitudes, emotions, values, and knowledge of students used by teachers as a benchmark to find out how far students understand the material being taught. According to Suprijono (2010: 7) "learning outcomes are changes in behaviour as a whole is not just one aspect of human potential alone. That is, learning outcomes categorized by educational experts as mentioned above are not seen fragmentary or separate, but comprehensive ". The high level of learning achievement of students depends on the learning process that occurs in students.

The subject of Marketing Strategy is a compulsory subject for the Marketing class. The purpose of this Marketing Strategy course is to teach students to have the knowledge, skills and attitudes of how to strategize used by employers or producers to do business. This course is selected because the material contained in the subject is appropriate when delivered using the Student Facilitator And Explaining (SFAE) model. Students in the discussion are invited to create an alignment strategy path to start a business that can make it easier for students to understand the material (Yu et al., 2017).

Based on the above problems, it is necessary to make efforts made by teachers to improve the quality of learning and student learning outcomes. Researchers have an alternative to providing solutions to these problems, namely the application of learning model SFAE (Student Facilitator and Explaining). This learning model is applied in order to encourage students to be more enthusiastic during the lesson and the students can master some skills, such as the ability to speak, explain the material that has been submitted by the teacher, listening, and understanding of the material (Irlinawati et al., 2013).

\section{METHOD}

This type of research is Classroom Action Research (PTK). This research uses a qualitative approach. This research stage was conducted in SMK YPI Darussalam 2 Cerme Gresik Regency. The subjects of the study were students of class X Marketing with 20 students. The technique of collecting data is done by observation, interview, documentation, test, and field note. The research instrument used is the teacher's precise observation sheet in applying the model, written test, field note, discussion sheet, and affective learning result sheet. This classroom action research is conducted in two cycles, in every 1 cycle consisting of two meetings. Each cycle has four stages: Planning action, Action, Observation, and Reflection.

Here is a process atua stage classroom action research by Arikunto, et al (2015:16). Here is a process or stage classroom action research by Arikunto, et al (2015: 16).

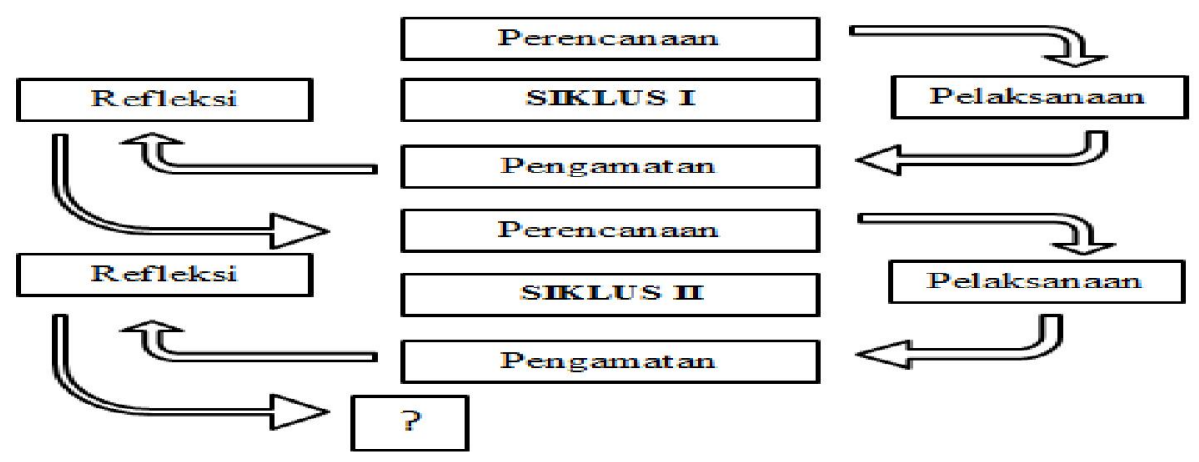

Figure 1 Classroom Action Research Flow Chart 


\section{DISCUSSION \& RESULT}

\section{Results}

The results of the study of data exposure in accordance with research objectives. The results obtained from this research is to know the use of learning model SFAE (Student facilitator And Explaining) on the subject of Marketing Strategy can improve student learning outcomes both in the cognitive and affective sphere obtained from the results of written tests and effective student observation sheet. The average cognitive learning outcomes of students in cycles I and II have increased when compared with pre-action, and affective side-to-face affects will be compared between cycles I and II. Increased learning outcomes for each cycle are described in Figures 1 and 2.

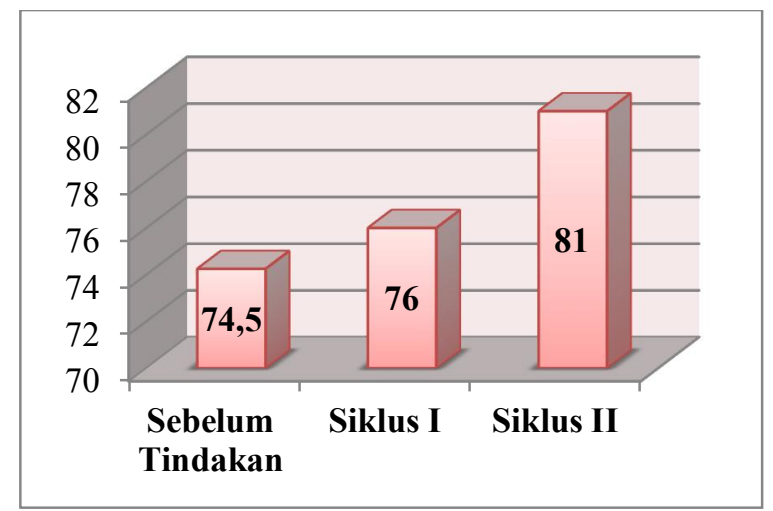

Figure 2 Average Learning Outcomes Cognitive Student Before Action, Cycle I and II

Figure 2 shows if there is an increase in student learning outcomes before action and after the action. The average value of cognitive learning outcomes of students before the implementation of the learning model of 74.5 when compared with student learning outcomes after the application of SFAE learning model. From the original total average learning outcomes, cognitive students in the first cycle of 76 and then on the second cycle has increased by 81 . This shows the positive results that the implementation of SFAE model can improve student learning outcomes in the cognitive domain.

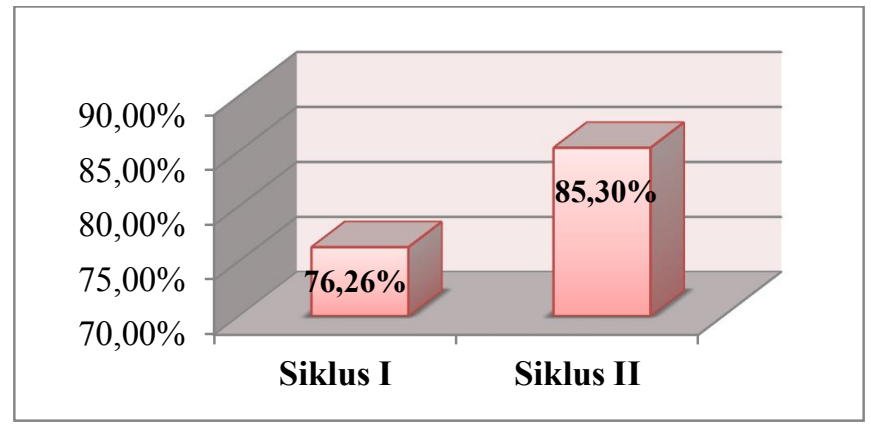

Figure 3 Average Learning Outcomes of the Affective Spheres of Cycle Students I and II

Berdasrakan Figure 3 shows the percentage of the total student learning outcomes effective cycle I cycle increased in cycle II. Results in cycle I got the overall percentage of 76.2, while in the second 
cycle has increased by 9.04 so that the total percentage of effective student learning outcomes to 85.30, it shows that the application of SFAE learning model can affect student affective learning outcomes.

\section{DISCUSSION}

The result of the research on the application of SFAE learning model has been observed by teacher and observer during the learning process which is shown through the observation sheet of teacher's accuracy in applying the model and field notes indicate that SFAE pursuit model can be considered effective because it can improve student learning result of $\mathrm{X}$ Marketing SMK YPI Darussalam 2 Cerme Kabupaten Gresik. Implementation of this learning model can make students to learn independently in making the concept of material understanding, but it can also encourage students to practice speaking skills, explain the teacher's explanation, and listening so as to improve student learning outcomes.

SFAE learning model has the meaning of methods that make students can create concept maps and charts to improve student creativity and student learning outcomes (Suprijono., 2010: 129). The Student Facilitator And Explaining (SFAE) learning model is one of the cooperative types of cooperative learning delivered to the material in which it describes a path or a structured process (Shoimin., 2014: 183). Huda (2013: 228-229) said that the SFAE learning model has 6 steps: (1) the teacher gives the competencies to be achieved, (2) the teacher demonstrates / presents the outline of the material, (3) gives the students the opportunity to explain to other students through draft or concept map, this is done in turns (4) the teacher summarizes the ideas / opinions of the students, (5) the teacher explains all the material presented, and (6) the cover.

SFAE learning model is a cooperative learning that is able to make students learn to cooperate and take responsibility in a group, students have two responsibilities, they are self-study and help fellow study group members (Rusman, 2012: 203; Mondejar et al., 2017; Supanc et al., 2017). Cooperative learning provides opportunities for students of different backgrounds and conditions to work together and rely on shared tasks and through cooperative learning, students are encouraged to be able to respect each other (Trianto, 2007: 44).

The success gained after the application of the SFAE learning model is found in the Strategic Marketing lesson, where the students become more active and interested during the learning process so that the learning objectives can be achieved. Students' understanding of the material also increases, as evidenced by the mutual response between teachers and students during the learning process. This is because the beginning of the teacher's learning only explains concretely about the outline of the material and the students are asked to create their own concept maps regarding their resistance to the material. It can also motivate students to be the best in explaining the material to represent the group. Activities during the lesson have also been predominated by the students, where the students act as facilitators and teachers provide guidance to students when arguing and reinforcing the material (Teerasong et al., 2010). Behind the success there are also some weaknesses during the implementation of the learning model, ie lazy students have the opportunity to remain passive in their group. The average learning outcomes can be seen in Tables 1 and 2 below:

Table 1. Average Percentage of Cognitive Learning Outcomes

Results of Cognitive Learning

\begin{tabular}{ccc}
\hline Before Action & Cycle I & Cycle II \\
\hline 74,5 & 76 & 81 \\
\hline
\end{tabular}

Table 2. Average Percentage of Affective Learning Outcomes 


\begin{tabular}{cc}
\hline \multicolumn{2}{c}{ Affective Learning Outcomes } \\
\hline Cycle I & Cycle II \\
\hline 76,26 & 85,30 \\
\hline
\end{tabular}

The improvement of students' cognitive learning outcomes is influenced by the use of the SFAE learning model that encourages students to create concept maps about their own understanding of the material. From the table above can be seen that the occurrence increased between the average results of student learning before action and after the action has increased in each cycle. By making their own concept of understanding about the material can improve students 'absorption of the taught material so as to improve students' cognitive learning outcomes. When viewed from Table 2 above, student learning outcomes in the affective domain also experienced an improvement, this is influenced by the discussion and presentation activities with the SFAE model can increase the activity and enthusiasm of students during the learning. This is in accordance with the results of research conducted by Zain et al (2012) that by applying SFAE learning model can improve student learning outcomes and social skills.

\section{CONCLUSION \& SUGGESTIONS}

\section{Conclusion}

SFAE learning model is very effectively applied in learning because can improve student learning outcomes both cognitive and affective sphere. This learning model also makes students more active when following the lesson. Students make their own understanding of the material taught, students are also encouraged to express opinions on the material according to his own understanding in front of the class so that students can provide a positive feedback between teachers and students during the learning takes place. The results of reseasrcgh also showed that the results of belajar in both the cognitive and affective areas increased after the application of SFAE learning model.

\section{Suggestion}

Based on the above conclusions, the suggestions are presented as follows. For schools, especially the curriculum in introducing the Student Facilitator And Explaining (SFAE) model of learning to teachers to make the learning process more active, so as to improve the quality and quality of education. Teachers can apply more varied models of teaching, besides teachers are also encouraged to motivate students to be more confident in expressing their opinions in front of the class.

\section{REFERENCES}

Amran, R., Yokoyama, F., \& Nishino. 2016. Development Of Active Learning Methods of English in Japan High Schools to Support Student Activities in Group Discussions. ProcediaSocial and Behavior Sciences, 96, 1471-1478. (Indonesian Origin).

Arikunto, S., Suhardjono, \& Supardi. 2015. Classroom Action Research. Jakarta: Earth Literacy. (Indonesian Origin).

Bohnen, JD, George, BC Williams, RG, Schuller, MC Darosa, DA, Tobeck, L., Mullen, JT, Meyerson, SL, Auyang, ED, Chipman, JG, Choi, JN Choti, MA, Endean, ED, foley, EF, Mandell, SP, Meier, AH, smink, DS, Terhune, KP, Wise, PE, Soper, NJ, Zwichenberger, JB, 
et al. 2016. The Feasibility of Real-Time Intraoperative Performance Assessment With SIMPL (System for Improving and Measuring Procedural Learning): Early Experience From a Multi-Institutional Trial. Journal of Surgical Education, 73, 118-130. (Indonesian Origin).

Hawlitschek, A., Joeckel, S. 2017. Increasing the Effectiveness of Digital Educational Games: The Effects of a Learning Instructions on Learning, Motivation and Cognitive Load. Computers in Human Behavior, 72, 78-86. (Indonesian Origin).

Huda, M. 2013. Teaching and Learning Models: Methodist and Paradigmatic Issues. Yogyakarta: Student Literature. (Indonesian Origin).

Irlinawati, D., Efendi, D., \& Andriani., S. 2013. Application of Student Facilitator And Explaining Learning Model on Multiplication Integral. Jurnal Pendidikan Matematika STKIP PGRI Sidoarjo, 1 (2), 2337-8166. (Indonesian Origin).

Kucukyilmaz, T., Cambazogu, B. B., Aykanat, C., Yates, R. B. 2017. Learning Style Identifier: Improving The Precision Of Learning Identification Though computational Intelligence Algorithms. Expert System with Applications, 75, 94-108. (Indonesian Origin).

Mondejar, L. M., \& Pastor, L. M. T. 2017. Development of Socio-emotional Skills though Cooperative Learning in a University Environment. Procedia-Social and Behavior Sciences, 237, 432-437. (Indonesian Origin).

Rusman. 2012. Learning Models: Develop Teacher Professionalism. Jakarta: Rajawali Pers. (Indonesian Origin).

Saricoban, A. 2014. Students' Opinions of Foreign Language Education on Constructivist Learning Environment. Procedia-Social and Behavior Sciences, 116, 2770-2773. (Indonesian Origin).

Shoimin, A. 2014. 68 Model of Innovative Learning in Curriculum 2013. Yogyakarta: Ar-Ruzz Media. (Indonesian Origin).

Su, X., Zhang, S. Yin, Y., Xiao, W. 2017. Prediction Model of permeability Index for Furnace Based On The Improved Multi-layer Extreme Learning Machine and Wavelet transform. Journal of the Franklin Institue. (Indonesian Origin).

Supanc, M., Vollinger, V. A., \& Brunstein, J.C. 2017. High-Structure Versus Low-Structure Cooperative Learning in Effects Conceptual Knowledge, Self-Perceived Competence, and Subjective Task Values. Learning and Instruction, in Press. (Indonesian Origin).

Suprijono, A. 2010. Cooperative Learning: Theory and Application of Paikem. Yogyakarta: Student Literature. (Indonesian Origin).

Supanc, M., Vollinger, V. A., \& Brunstein, J.C. 2017. High-Structure Versus Low-Structure Cooperative Learning in Effects Conceptual Knowledge, Self-Perceived Competence, and Subjective Task Values. Learning and Instruction, in Press. (Indonesian Origin). 
Teerasong, A. 2010. Development of a Predict Observe Explain Strategy for Teaching Flow Injection in Undergraduate Chemistry. The International Journal of Learning, 17 (8), 137-150.

Trianto. 2007. Innovative Learning Models are Constructivistically Oriented. Jakarta: Achievement Library. (Indonesian Origin).

Tyabaev, A. E., Sedelnikova, S. F., \& Voytovich, A. V. 2015. Student-centered Learning: The Experience of Teaching International Students in Russian Universities. Procedia-Social and Behavior Sciences, 215, 84-89.

RI Law No.20 of 2003 on National Education System. Vocational Education. (Online), (http: // sindi kker.dikti.go id / doc / Act / Act 20-2003-Sisdiknas.pdf). (Indonesian Origin).

Yilmaz, R. 2017. Exploring the Role of E-Learning Readiness on Student Satisfaction and Motivation in Flipped Classroom. Computers in Human Behavior, 70, 251-260. (Indonesian Origin).

Yu, W., Ramanathan, R., \& Nath, P. 2017. Environmental Pressures and Performance: AN Analysis of the Role of Environmental Innovation Strategy and Marketing Capability. Technological Forecasting and Social Change, 117, 160-169. (Indonesian Origin).

Zain, A. R \& Joko. 2012. The Influence of Cooperative Learning Model Type Student Facilitator And Explaining (SFAE) on Student Results in Standard Competence Interpreting Electrical Engineering Picture SMKN 2 Pamekasan. Journal of Electrical Engineering Education, 1 (2): 40-46. (Indonesian Origin). 